DOI: https://doi.org/10.47405/mjssh.v6i12.1208

\begin{tabular}{|c|c|}
\hline and & Malaysian Journal of Social Sciences and Humanities (MJSSH) \\
\hline $\begin{array}{l}\text { Malaysian Journal of } \\
\text { Soly }\end{array}$ & Volume 6, Issue 12, December 2021 \\
\hline (MJ-sSH) & e-ISSN : 2504-8562 \\
\hline & $\begin{array}{l}\text { Journal home page: } \\
\text { www.msocialsciences.com }\end{array}$ \\
\hline
\end{tabular}

\title{
Tinjauan Sistematik: Persepsi Guru Terhadap Penggunaan Gamifikasi
}

\author{
Angela Pao Sheng Mei ${ }^{1}$, Shahlan Surat ${ }^{1}$ \\ ${ }^{1}$ Falkulti Pendidikan, Universiti Kebangsaan Malaysia (UKM), Malaysia \\ Correspondence: Angela Pao Sheng Mei (p105538@siswa.ukm.edu.my)
}

\begin{abstract}
Abstrak
Guru sebagai pengurus bilik darjah memainkan peranan penting mempelbagaikan menggunakan kaedah dan pendekatan pengajaran yang berbeza untuk melaksanakan pembelajaran aktif. Tinjauan literatur sistematik ini dilakukan untuk mendapatkan persepsi guru terhadap penggunaan gamifikasi dalam pengajaran dan pembelajaran dalam tempoh 2016 hingga 2021. Pendekatan sistematik PRISMA (Preferred Reporting Items for Systematic Review and Meta-Analyses) digunakan sebagai metodologi kajian. Sejumlah 15 artikel yang berkaitan dengan persepsi guru terhadap penggunaan gamifikasi dipilih dari tiga pangkalan data iaitu Science Direct, IEEE Xplore, dan ERIC dianalisis dan disintesis secara menyeluruh. Secara keseluruhan, hasil kajian ini menunjukkan bahawa gamifikasi diterima secara positif di kalangan guru kerana keberkesanan, kemudahan penggunaan, dan memberi motivasi kepada sifat pelajar. Di samping itu, kesan negatif gamifikasi kepada murid juga dinyatakan dan dianalisis dalam tinjauan ini. Tinjaunan sistematik hanya mengulas 15 artikel tersebut dengan menggunakan kriteria kelayakan dan pengecualian khusus. Kebanyakan artikel yang ditinjau menggunakan kaedah pengumpulan data self-reported seperti tinjauan, temu ramah, dan perbincangan kumpulan fokus. Pendekatan gamifikasi memberi kesan positif kepada guru dan menyebabkan guru lebih menerima platform ini sekarang. Namun, masih ada ruang untuk gamifikasi diperbaiki untuk menghadapi kesan negatif yang dinyatakan. Cadangan untuk penyelidikan masa depan diberikan.
\end{abstract}

Kata kunci: gamifikasi, persepsi guru, tinjauan sistematik, pembelajaran berasaskan permainan, pendidikan

\section{Teachers' Perceptions of the Use of Gamification: A Systematic Review}

\begin{abstract}
Teachers as classroom managers play an important role in diversifying the use of different teaching methods and approaches to implement active learning. This systematic literature review was conducted to obtain teachers' perceptions on the use of gamification in teaching and learning from 2016 to 2021. PRISMA (Preferred Reporting Project for Systematic Evaluation and Meta-Analysis) was used as the research method. 15 articles related to the teachers' perceptions on the use of gamification were selected from the three databases namely Science Direct, IEEE Xplore and ERIC for thorough analysis and synthesis. Overall, the results of this study indicate that gamification is positively accepted among teachers because of its effectiveness, ease of use, and motivating nature of students. In addition, the negative effects of gamification on pupils were also noted and analyzed in this survey. The systematic review only reviewed the 15 articles using specific eligibility and exclusion criteria. Most of the reviewed articles used self-reported data collection methods such as surveys, interviews, and focus group discussions. The gamification approach has had a positive impact on teachers and is causing
\end{abstract}


teachers to be more receptive to this platform now. However, there is still room to improve gamification to deal with the negative impact expressed. Suggestions for future research are given.

Keywords: gamification, teacher perception, systematic review, game-based learning, education

\section{Pengenalan}

Gamifikasi merujuk kepada penggunaan elemen reka bentuk permainan dalam konteks bukan permainan (Domínguez et al., 2013; Ding et al., 2018; Zimmerling et al., 2019; Schöbel et al., 2020). Gamifikasi juga ditakrif sebagai konsep yang berkembang dengan era teknologi kerana merangkumi strategi dan cara baru untuk mengembangkan pembelajaran (Chow et al., 2011). Pendekatan ini dibina berdasarkan pembelajaran konstruktivisme yang merumuskan perlunya pembelajaran berdasarkan pengalaman melalui interaksi sosial dengan persekitaran dan rakan sebaya (York \& deHaan, 2018). Terdapat bukti yang banyak telah menunjukkan bahawa peningkatan penerimaan gamifikasi sebagai strategi pembelajaran berkesan yang digunakan untuk mewujudkan pengalaman pembelajaran yang menarik. Berdasarkan bukti empirikal kajian terkini, kejayaan permainan digital dalam konteks pendidikan telah berusaha mengesahkan kesan gamifikasi dengan potensinya untuk meningkatkan motivasi, penglibatan dan pengaruh sosial (Groening \& Binnewies, 2019; Lopez \& Tucker, 2019). Walau bagaimanapun, sokongan dan penglibatan gamifikasi dalam pedagogi tetap mencabar (Ding et al., 2018). Tambahan lagi, konsep gamifikasi masih baru dalam sektor pendidikan (Göksün \& Gürsoy, 2019).

Guru sebagai pengurus bilik darjah memainkan peranan penting untuk membina suasana pembelajaran yang kondusif dan menyeronokkan. Guru harus menggunakan kaedah dan pendekatan pengajaran yang berbeza dan teknik baru untuk melaksanakan pembelajaran aktif bagi meningkatkan motivasi dan penglibatan pelajar dalam pembelajaran dan pendekatan dan teknik baru untuk melaksanakan pembelajaran aktif. Oleh itu, satu pertimbangan penting dalam penggunaan gamifikasi yang paling berkesan adalah mendapatkan persepsi guru terhadap penggunaan gamifikasi. Persepsi guru memberi implikasi yang kuat terhadap pengajaran guru dalam kelas. Tingkah laku guru dipengaruhi oleh individu, persekitaran sosial, fizikal dan faktor tahap dasar boleh memberi kesan kepada keputusan yang dibuat oleh guru berkenaan dengan pendekatan pedagogi diterima pakai (Elder et al., 2007). Menurut Kotler (2000), persepsi menerangkan proses bagaimana seseorang memilih, mengatur, dan mentafsirkan input maklumat untuk menghasilkan konsep keseluruhan yang bermakna. Pajares (1992) pula mendakwa bahawa persepsi guru mempunyai erti yang sama dengan kepercayaan guru, iaitu keyakinan peribadi terhadap pengajaran, peranan tanggungjawab, pelajar, kurikulum, dan bilik darjah.

Persepsi guru dipengaruhi oleh faktor luaran seperti dasar dan kurikulum serta faktor dalaman, iaitu minat dan sikap peribadi ke arah permainan. Kajian Koh et al. (2012) telah menunjukkan bahawa guru bersetuju penggunaan permainan di bilik darjah mereka menunjukkan hasil yang positif. Penyelidik telah melakukan beberapa tinjauan mengenai persepsi guru berkaitan permainan digital (Fokides \& Kaimara, 2020; Kaimara et al., 2019b; Kaimara \& Fokides, 2019). Data kuantitatif telah menunjukkan bahawa, guru terlatih enggan menggunakan permainan digital sebagai alat pendidikan walaupun guru terlatih nampaknya bersetuju bahawa kaedah pengajaran tersebut memberi kesan positif kepada pelajar. Faktor yang mempengaruhi sikap guru terlatih adalah pengalaman permainan dan tahap kemahiran teknologi. Hasil dapatan membawa kepada keperluan untuk menyelidik lebih lanjut untuk sebab-sebab yang membentuk pendapat guru (Fokides \& Kaimara, 2020). Oleh itu, tinjauan sistematik dilakukan untuk mengetahui pandangan guru terhadap penggunaan gamifikasi dalam pengajaran dan pembelajaran.

\section{Sorotan Literatur}

\section{Konteks Gamifikasi Dalam Pendidikan}

Permainan semakin relevan dan menarik sebagai sumber pendidikan dalam pelbagai persekitaran pendidikan dengan pertumbuhan telefon pintar dan teknologi interaktif (Ge, 2018). Oleh itu, teknik 
gamifikasi digunakan dalam persekitaran pendidikan untuk memotivasi pelajar dan sering memanfaatkan keperluan persaingan kebanyakan orang untuk mendorong tindakan yang berjaya (Rizzardini et al., 2016). Gamifikasi dapat mendorong permulaan atau mengekalkan tingkah laku berorientasikan matlamat dan motivasi dalam semua bidang (Sailer et al., 2017). Di samping itu, gamifikasi adalah fenomena pendidikan yang semakin meningkat kerana kesannya terhadap pembelajaran pelajar (da Rocha Seixas et al., 2016; Göksün dan Gürsoy, 2019). Selain itu, ini adalah kaedah instruksional untuk meningkatkan pengajaran, memberi inspirasi dan memperkasakan, meningkatkan penglibatan serta interaktiviti pelajar, dan mendorong pelajar untuk mengembangkan kemahiran mereka (Zainuddin et al., 2020b). Ding (2019) menjelaskan bahawa komponen gamifikasi mendorong pelajar untuk memperoleh lebih banyak orientasi tujuan melalui kesabaran yang lebih signifikan, pembelajaran berulang, kerja berpasukan, dan persaingan yang menyenangkan dengan orang lain semasa proses pembelajaran.

Terdapat bukti yang semakin meningkat bahawa gamifikasi semakin diterima sebagai strategi pembelajaran yang berkesan untuk mewujudkan pengalaman pembelajaran yang sangat menarik. Menurut bukti empirikal dari penyelidikan baru-baru ini, kejayaan permainan digital dalam pendidikan berusaha untuk mengesahkan kesan gamifikasi dalam menyokong potensinya untuk meningkatkan motivasi, penyertaan, dan kesan sosial, sambil melibatkan pelajar dalam pembelajaran pengalaman (Groning \& Binnewies, 2019; Lopez \& Tucker, 2019). Kajian Frost et al. (2015) telah menunjukkan bahawa gamifikasi dapat mendorong minat pelajar dan memenuhi keperluan berkaitan; lebih-lebih lagi, ia memberi kesan positif terhadap motivasi mereka dan memberikan maklum balas yang tersendiri dan bermakna terhadap kesilapan. Walau bagaimanapun, unsur persaingan nampaknya kurang menarik bagi kanak-kanak perempuan berbanding dengan kanak-kanak lelaki (Kickmeier-Rust et al., 2014). Sun dan Hsieh (2018) mencadangkan bahawa kursus bahasa Inggeris harus merangkumi elemen permainan, kerana pelajar cenderung lebih berminat dan kompetitif dalam kursus, serta alat untuk memastikan mereka lebih fokus di dalam kelas. Su dan Cheng (2015) menyatakan bahawa kursus gamifikasi bukan hanya dapat meningkatkan motivasi pelajar, tetapi juga meningkatkan pencapaian mereka.

\section{Kelebihan Penggunaan Gamifikasi kepada Guru}

Gamifikasi boleh menjadi alat yang berharga untuk memperoleh pengetahuan dan meningkatkan keupayaan penting seperti membuat keputusan, kerjasama, dan komunikasi (Dicheva et al. 2015). Selain itu, pelajari kemahiran abad ke-21 dan sediakan persekitaran yang berkesan dan sesuai untuk penilaian, komunikasi dan penyertaan di bilik darjah dengan rakan sekerja. Gamifikasi dalam persekitaran pendidikan meningkatkan hubungan antara pelajar dan guru dan meningkatkan kreativiti mereka (Brifa et al., 2020). Oleh itu, gamifikasi dalam pengajaran dianggap kaedah bijaksana untuk mempercepat pembelajaran, mengajar mata pelajaran yang rumit, dan pemikiran sistem (Ding et al., 2018). Walau bagaimanapun, gamifikasi fleksibel kerana dapat memenuhi sebahagian besar keperluan pembelajaran, termasuk penjualan produk, perkhidmatan pelanggan, kemahiran insaniah, peningkatan kesedaran, dan lain-lain, sehingga membawa peningkatan prestasi kepada organisasi (Furdu et al., 2017).

\section{Cabaran dalam Pelaksanaan Pendekatan Gamifikasi}

Dalam beberapa tahun kebelakangan ini, gamifikasi menimbulkan minat yang meluas dalam rangkaian ahli akademik dan penyelidik, mendorong mereka untuk meneroka pelbagai elemen gamifikasi sebagai sebahagian dari proses reka bentuk instruksional untuk memberikan pengalaman yang menarik dan program yang disempurnakan (Kyewski \& Kramer, 2018; Tsay et al., 2018). Walaupun perkembangan teknologinya dan kesannya yang besar terhadap pembelajaran dan pengajaran, sokongan dan kekalan penyertaan dalam pedagogi gamified masih mencabar (Ding et al., 2018). Menurut Zainuddin et al. (2020), penyebab utama mengapa pembelajaran dengan aplikasi gamifikasi tidak berjaya adalah penggunaan elemen permainan, reka bentuk instruksional, dan masalah teknikal. Halangan seperti masalah bilik darjah dan infrastruktur teknologi, contohnya, komputer yang tidak berfungsi atau gangguan bekalan elektrik dan internet. Guru ragu-ragu menggunakan elemen gamifikasi dalam rancangan pengajaran mereka kerana mereka tidak mempercayai konsep itu sendiri dan kemampuannya untuk meningkatkan pemahaman pelajar. (Jong et al. 2015). Di samping itu, pereka pendidikan perlu 
memperoleh pemahaman empirikal mengenai perkara berikut: hasil, objektif pembelajaran, dan kandungan; semasa menilai pilihan permainan individu (Derfer-Rozin \& Pitesa, 2020).

Kajian-kajian lepas menunjukkan bahawa menggunakan elemen gamifikasi telah gagal meningkatkan rasa berkumpulan pelajar dan tidak meningkatkan bakat, keinginan untuk berprestasi, dan inspirasi dalaman pelajar (Mekler et al., 2017; Kyewski dan Krämer, 2018). Di samping itu, pembelajaran yang inovatif melalui permainan juga memerlukan usaha dari guru dan pelajar. Pembelajaran digital dalam masyarakat pengetahuan masa kini dicirikan oleh ciri-ciri yang tidak terkawal melalui masa dan tempat (Al-Azawi et al., 2016). Oleh itu, cara untuk memenuhi keperluan setiap pemain mesti dipertimbangkan untuk memastikan permainan tertentu (Brifa et al., 2020). Menurut Gartner (2015), kira-kira 80 peratus daripada semua aplikasi permainan tidak akan berjaya kerana reka bentuk yang tidak sesuai (Urh et al., 2015). Pada pandangan pengkritik, gamifikasi menghalang pendidikan melalui desentralisasi, tekanan melalui persaingan yang tidak diperlukan, dan kemungkinan kekurangan keperluan pendidikan bagi pelajar tertentu (Sánchez-Mena \& Martí-Parreño, 2017). Sebaliknya, gamifikasi dalam proses pendidikan tidak selalu bermaksud bahawa penajaan atau penyertaan pelajar bukan sekadar motivasi luaran, seperti ganjaran maya atau mata pencapaian (Zainuddin et al., 2020).

\section{Metod Kajian}

Tinjauan sistematik dipilih untuk menggambarkan, menilai dan mensintesiskan kajian empirikal semasa dalam persepsi guru terhadap gamifikasi dengan memandangkan kekuatan metodologinya sebagai kaedah untuk mewujudkan asas bukti yang komprehensif dan boleh dipercayai (Gough etal., 2012, h. 2). Untuk memastikan kajian yang dilakukan bersistematik, garis panduan penyataan Preferred Reporting Items for Systematic Reviews and Meta-Analyses (PRISMA) dipertimbangkan (Moher et al., 2009).

\section{Kriteria Penerimaan}

Kriteria penerimaan artikel adalah kajian yang menggambarkan dan meneroka persepsi guru terhadap gamifikasi. Jenis artikel yang diterima ialah jurnal peer-reviewed. Responden utama kajian adalah guru pelatih dan guru dalam perkhidmatan. Tahun penerbitan kajian adalah antara 2016 dan 2021. Bahasa penerbitan artikel adalah ditulis dalam Bahasa Inggeris. Kajian mesti secara jelas menerangkan metodologi, dan data yang membuat kesimpulan. Dapatan kajian yang sah dan boleh dipercayai dari segi jenis kajian.

\section{Kriteria Pengecualian}

Kriteria pengecualian artikel adalah kajian yang tanpa bukti empirikal dan artikel yang tidak berkaitan dengan kehendak tajuk yang dicari. Tahun artikel yang sebelum tahun 2016 tidak akan diterima apabila membuat pemilihan artikel. Selain itu, artikel seperti prosiding buku, sorotan kajian dan sebagainya tidak diterima. Bahasa yang selain daripada bahasa Inggeris juga tidak akan diterima.

\section{Carian Strategi}

Kajian skop awal mengenal pasti tiga pangkalan data iaitu Science Direct, IEEE Xplore, dan ERIC. Tinjauan tidak rasmi berkaitan relevan sastera dibuat untuk merumuskan senarai istilah yang menerangkan konsep persepsi dan gamifikasi. Istilah carian yang dikembangkan untuk carian pangkalan data merangkumi istilah persepsi, istilah gamifikasi dan istilah guru. Pencarian perintis pada istilah tunggal dan gabungan dilakukan sebelum memutuskan senarai kata kunci terakhir. Pencarian sistematik dilakukan bagi setiap istilah gabungan. Empat pangkalan data tersebut dicari dengan menggunakan serangkaian kata kunci berdasarkan rentetan logik Boolean seperti berikut:

(“teacher” OR “educator”) AND (“attitude” OR “belief” OR “perception” OR “perspective” OR "views") AND ("gamified" OR "gamification") 


\section{Pemilihan Kajian}

Pencarian pangkalan data menyampaikan sejumlah 725 artikel berpotensi berdasarkan pada carian serangkaian kata kunci yang luas ini. Semasa carian pertama, pencarian awal mengenal pasti 171 rekod dari pangkalan data yang dipilih dengan mempertimbangkan kriteria kelayakan. Walau bagaimanapun, banyak kajian telah berduplikasi. Setelah menyelesaikan masalah duplikasi, sebilangan kecil kajian memenuhi kriteria kelayakan dimasukkan untuk peringkat penyaringan tajuk dan abstrak tinjauan. Artikel-artikel disaring dengan mengkaji tajuk, abstrak, dan rujukan bibliografi. Oleh itu, saringan menghasilkan 64 kajian, teks lengkap yang diperoleh untuk diperiksa menggunakan kriteria kelayakan. Dari 64 kajian yang dihasilkan dari pencarian pangkalan data, 15 telah dikeluarkan berdasarkan kriteria kelayakan. Akhirnya, strategi pencarian diaplikasikan menghasilkan sampel kajian $\mathrm{n}=15$ yang kemudian dinilai berdasarkan kualiti dan kesesuaiannya.

Rajah 1: Carta Alir Pemilihan Sampel

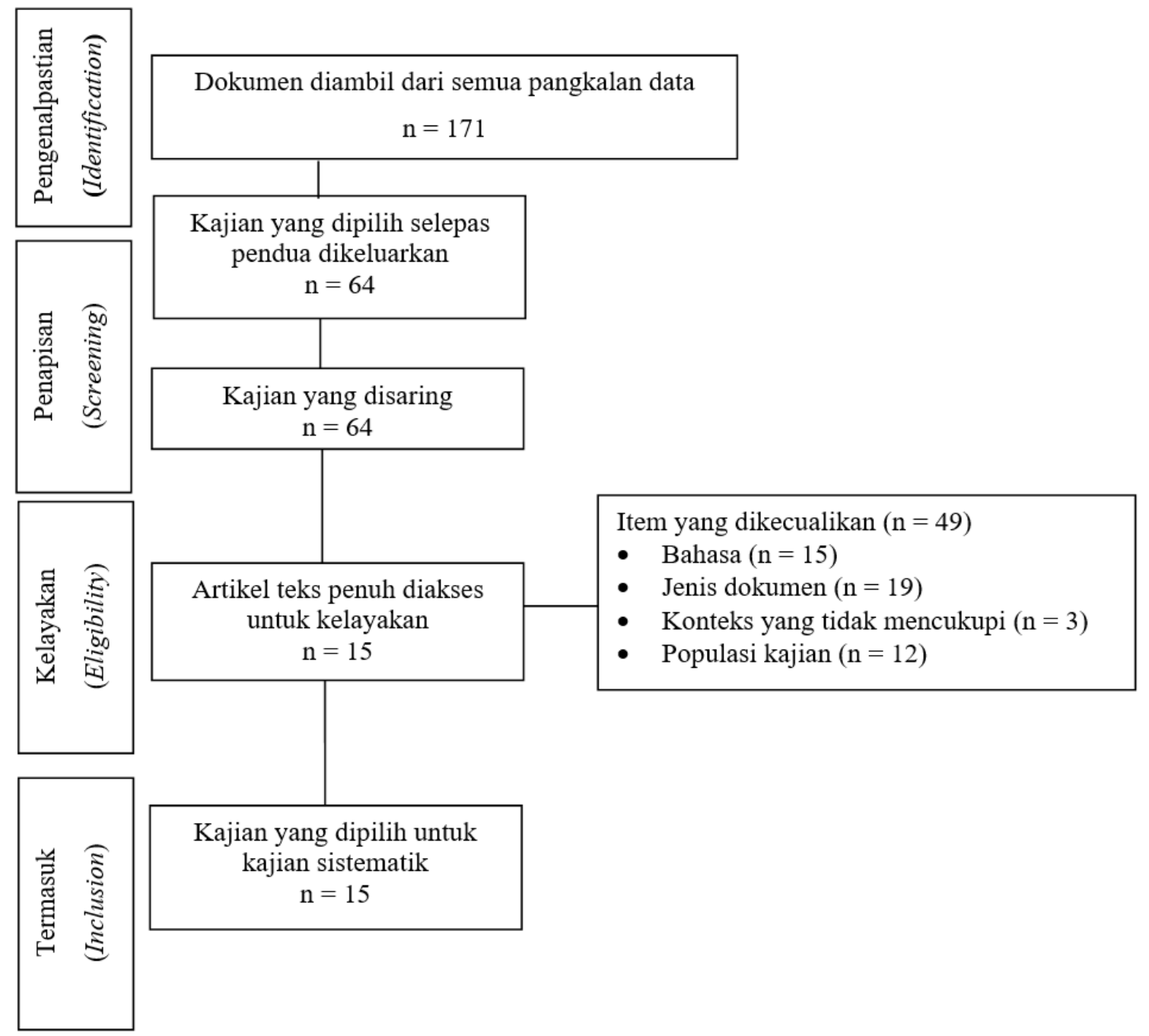

Sumber: Carta Alir PRISMA Moher et al. (2009)

\section{Dapatan Kajian}

Bahagian ini menunjukkan hasil dari proses pemilihan artikel kajian yang dijumpai akan dibincangkan secara terperinci. Setelah empat fasa pemilihan artikel, sebanyak 15 artikel kajian telah dipilih berdasarkan kriteria kelayakan yang telah ditetapkan. Data diekstrak berdasarkan protokol tinjauan yang dibina. 


\section{Pembahagian Kajian dalam Masa}

Apabila artikel yang dipilih diklasifikasikan berdasarkan tahun penerbitan, kita dapat melihat bahawa lebih banyak artikel diterbitkan pada tahun 2020 (5 artikel) dan diikuti 4 artikel pada tahun 2019 manakala 1 artikel pada tahun 2017, masing-masing 2 artikel pada tahun 2016 dan 2018. Ini selari dengan tinjauan Pew Research Center, yang menunjukkan sebanyak 53\% orang menyatakan bahawa, penggunaan gamifikasi akan tersebar luas pada tahun 2020 (Pew Research Center, 2012).

\section{Rajah 2: Bilangan kajian yang diterbitkan mengikut tahun}

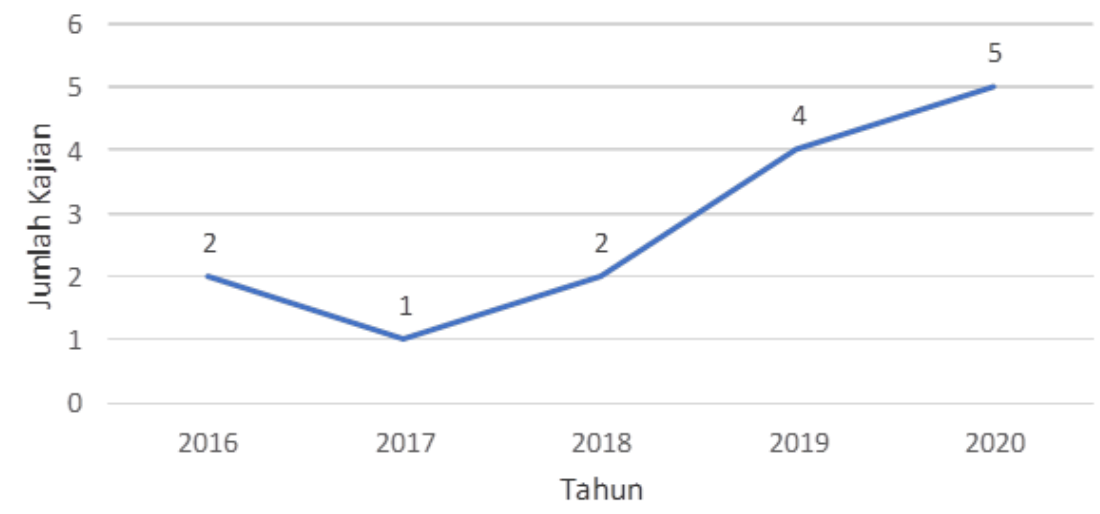

Apabila artikel yang dipilih diklasifikasikan berdasarkan tahun penerbitan, kita dapat melihat bahawa lebih banyak artikel diterbitkan pada tahun 2020 (5 artikel) dan diikuti 4 artikel pada tahun 2019 manakala 1 artikel pada tahun 2017, masing-masing 2 artikel pada tahun 2016 dan 2018. Ini selari dengan tinjauan Pew Research Center, yang menunjukkan sebanyak 53\% orang menyatakan bahawa, penggunaan gamifikasi akan tersebar luas pada tahun 2020 (Pew Research Center, 2012).

\section{Lokasi Kajian}

Para responden dalam artikel kajian yang dikaji adalah dari pelbagai negara di seluruh dunia, kebanyakannya di Sepanyol $(n=4)$, Turki $(n=4)$, Arab Saudi $(n=2)$, Bulgaria $(n=1)$, Malaysia $(n=$ $1)$, Afrika Selatan $(n=1)$, dan pelbagai negara $(n=1)$. Pendekatan gamifikasi dalam pendidikan digunakan secara meluas di sekitar dunia. Gamifikasi menjadi semakin popular dan banyak digunakan berbanding sebelumnya. Ramalan bagi kadar pertumbuhan pembelajaran berasaskan permainan 2019 hingga 2024 untuk tujuh wilayah iaitu Eropah Barat muncul dengan kadar pertumbuhan tertinggi 47.2\%, Eropah Timur diikuti 42.2\%, Afrika 41.3\%, Timur Tengah 36.2\%, Amerika Utara 35.2\%, Amerika Latin $30.1 \%$, dan Asia Pasifik 27\% (Metaari, 2019).

\section{Profil Peserta}

Kajian semasa memberi tumpuan kepada gamifikasi dalam pendidikan. Oleh itu, kajian tentang persepsi guru pelatih dan guru dalam perkhidmatan telah diterokai. Daripada 15 kajian yang dikaji semula, 5 dilakukan dengan guru pelatih yang menggunakan pendekatan gamifikasi; 9 dilakukan dengan guru dalam perkhidmatan yang menggunakan pendekatan gamifikasi. Hanya satu kajian yang melibatkan guru pelatih dan guru dalam perkhidmatan yang menggunakan pendekatan gamifikasi.

\section{Reka Bentuk Kajian}

Terdapat tiga kaedah kajian yang digunakan, iaitu kualitatif, kuantitatif, dan kaedah campuran bagi menjana atau mengumpulkan kajian data. Berdasarkan analisis reka bentuk kajian, 6 artikel dalam tinjauan literatur ini yang menggunakan kaedah kuantitatif, 5 artikel kajian menggunakan kaedah kualitatif dan 4 artikel kajian menggunakan kaedah campuran. Daripada keseluruhan 15 artikel kajian, reka bentuk kajian kuantitatif banyak digunakan oleh pengkaji-pengkaji lepas dalam mengkaji persepsi 
guru terhadap gamifikasi. Jadual 1 menyenaraikan semua instrumen yang digunakan untuk pengumpulan data dalam kajian yang dikaji.

Jadual 1: Bilangan kajian berdasarkan reka bentuk kajian

\begin{tabular}{lll}
\hline Kaedah & Pengumpulan data \& Instrumen & N \\
\hline Kuantitatif & Soal selidik & 5 \\
$(\mathrm{n}=6)$ & Soal selidik atas talian & 1 \\
Kualitatif & Temu bual separa berstruktur & 1 \\
$(\mathrm{n}=5)$ & Temu ramah berstruktur atas talian & 1 \\
& Soal selidik terbuka & 1 \\
& Tiga bahagian tinjauan (skala Likert lima mata) & 1 \\
& Soal selidik terbuka \& Temu ramah klinikal \\
Campuran & Soal selidik atas talian \& Temu ramah susulan & 1 \\
$(\mathrm{n}=4)$ & Subscale Intrinsic Motivation \& Lukisan, Kumpulan, Perbincangan, & 1 \\
& Buku Harian Guru & 1 \\
& Kumpulan fokus, Temu ramah separa berstruktur \& Soal selidik & 1 \\
& Soal selidik \& Soalan terbuka & 1 \\
\hline
\end{tabular}

\section{Persepsi Guru Terhadap Penggunaan Gamifikasi}

Dari 15 artikel, empat aspek utama persepsi guru terhadap penggunaan gamifikasi dapat dilihat dari segi keberkesanan, kebolehlaksanaan, kesukaran, motivasi dan kesan negatifnya. Hasil kajian disenaraikan pada Jadual 2.

Jadual 2: Aspek persepsi guru terhadap gamifikasi

\begin{tabular}{|c|c|c|c|c|}
\hline \multirow{2}{*}{ Pengarang } & \multicolumn{4}{|c|}{ Perspektif } \\
\hline & Keberkesanan & Kesukaran & Motivasi & Kesan Negatif \\
\hline Yunjo An et al. (2020) & $\sqrt{ }$ & $\sqrt{ }$ & & $\sqrt{ }$ \\
\hline Asiri, M. (2019) & $\sqrt{ }$ & & & \\
\hline H. Yaşar et al. (2020) & $\sqrt{ }$ & $\sqrt{ }$ & $\sqrt{ }$ & $\sqrt{ }$ \\
\hline $\begin{array}{c}\text { Sánchez-Mena \& Martí-Parreño } \\
(2017)\end{array}$ & $\sqrt{ }$ & & $\sqrt{ }$ & $\sqrt{ }$ \\
\hline Fernandez-Rio, J et al. (2020) & $\sqrt{ }$ & $\sqrt{ }$ & $\sqrt{ }$ & \\
\hline Ekmel Çetin, Ebru Solmaz (2020) & $\sqrt{ }$ & $\sqrt{ }$ & & \\
\hline Jong, M (2019) & & & & \\
\hline Adukaite, A and Cantoni, L (2016) & $\sqrt{ }$ & $\sqrt{ }$ & $\sqrt{ }$ & \\
\hline Başal, A. \& Kaynak, N. E. (2019) & $\sqrt{ }$ & & $\sqrt{ }$ & \\
\hline Martí-Parreñoa, J et al. (2016) & & $\sqrt{ }$ & & \\
\hline Mee et al. (2020) & $\sqrt{ }$ & $\sqrt{ }$ & & $\sqrt{ }$ \\
\hline Alabbasi, D. (2018) & $\sqrt{ }$ & & $\sqrt{ }$ & $\sqrt{ }$ \\
\hline Pektaş, M. \& Kepceoğlu, I (2019) & $\sqrt{ }$ & $\sqrt{ }$ & $\sqrt{ }$ & $\sqrt{ }$ \\
\hline Tuparova, D. et al. (2018) & $\sqrt{ }$ & $\sqrt{ }$ & & \\
\hline Gómez-Carrasco, C. et al. (2019) & & & $\sqrt{ }$ & \\
\hline
\end{tabular}

Sebanyak 11 artikel yang membincangkan keberkesanan gamifikasi, 5 artikel menujukan persepsi kebolehlaksanaan gamifikasi dalam pendidikan, 10 artikel menyatakan kesukaran penggunaannya, 6 artikel membincangkan kesan motivasi terhadap murid dan 3 artikel lagi telah menyatakan kesan negatif gamifikasi. 


\section{Perbincangan}

Persepsi guru terhadap penggunaan gamifikasi dalam pengajaran dan pembelajaran akan dibincangkan dalam lima aspek utama, keberkesanan, kebolehlaksanaan, kesukaran, motivasi dan kesan negatif.

\section{Persepsi Guru Terhadap Keberkesanan Gamifikasi}

Sebanyak 11 daripada 15 kajian membincangkan persepsi guru berkaitan keberkesanan gamifikasi dalam pengajaran dan pembelajaran. Setelah membaca 15 artikel yang dipilih dari sebilangan besar artikel kajian, kebanyakan guru bersetuju bahawa gamifikasi berkesan dalam pendidikan. Guru dari pelbagai negara bersetuju terhadap keberkesanan gamifikasi terutama dalam membantu pelajar belajar dalam persekitaran yang menyeronokkan, interaktif, dan bermakna (Başal \& Kaynak, 2019; Pektaş \& Kepceoğlu, 2019; Yaşar et al., 2020; Mee et al., 2020; An et al., 2020; Fernandez-Rio, 2020). Gamifikasi berpotensi untuk dimanfaatkan dengan pelbagai cara, termasuk penilaian dan pedagogi pengajaran (Adukaite \& Cantoni, 2016; Alabbasi, 2018; Tuparova et al., 2018; Murat \& İbrahim, 2019). Çetin \& Solmaz (2020) menyatakan bahawa alat Sistem Respons Interaktif berasaskan gamifikasi (IRS) dapat menarik perhatian pelajar untuk belajar dan meningkatkan pengekalan serta pemindahan ilmu pengetahuan (An et al., 2020). Ini adalah disebabkan penggabungan elemen permainan dalam pembelajaran memerlukan pelajar memperoleh mata yang banyak dengan menyelesaikan sesuatu tugasan yang ditetapkan (Fernandez-Rio, 2020). Ini secara langsung memupuk sikap daya saing pelajar. Sifat ingin menang manusia telah mendorong pelajar berusaha keras untuk meningkatkan pencapaian pembelajaran (Başal \& Kaynak, 2019; Asiri, 2019; Pektaş \& Kepceoğlu, 2019; An et al., 2020; Yasar et al., 2020).

Tambahan lagi, gamifikasi membantu meningkatkan pengetahuan (Adukaite \& Cantoni, 2016; An et al., 2020) dan kemahiran insaniah asas pelajar seperti berkolaborasi (Pektaş \& Kepceoğlu, 2019), berkomitmen untuk mencapai matlamat (Fernandez-Rio, 2020), berfikir secara kreatif, kritis dan penyelesaian masalah (Tuparova et al., 2018; Mee et al., 2020). Penggabungan elemen permainan juga dipercayai dapat mengurangkan ketekanan pembelajaran dan memotivasikan pelajar untuk mencapai prestasi yang lebih baik (Mee et al., 2020). Hal ini mungkin disebabkan penggabungan elemen permainan yang memberi pelajar tahap autonomi tertentu dan membolehkan mereka mengawal proses pembelajaran (Alabbasi, 2018). Menurut Yaşar et al. (2020), gamifikasi boleh diperlihatkan sebagai alat yang dapat menggalakkan tabiat belajar yang baik bagi membantu pelajar mencapai tujuan pembelajaran.

\section{Persepsi Guru Terhadap Kesukaran Gamifikasi}

Gamifikasi adalah konsep yang agak menarik dan baru dalam bidang pembelajaran. Namun begitu, terdapat banyak cabaran yang telah dihadapi oleh guru dalam melaksanakan gamifikasi. Dari 15 artikel kajian yang dikenal pasti, 9 membincangkan persepsi guru berkaitan tahap kesukaran menggunakan gamifikasi. Contohnya, guru senior yang menyatakan bahawa beliau tidak berminat untuk menggunakan gamifikasi kerana tidak tahu menggunakan platform (An et al., 2020). Faktor usia (An et al., 2020; Martí-Parreño, 2016) dan masa juga telah menjadi alasan biasa yang diberikan oleh guru untuk tidak menggunakan gamifikasi dalam sesi pengajaran dan pembelajaran (An et al., 2020; Adukaite \& Cantoni, 2016; Sánchez-Mena \& Martí-Parreño, 2017; Tuparova et al., 2018; Fernandez-Rio et al., 2020; Mee et al., 2020). Walau bagaimanapun, kesukaran ini dapat diatasi dengan mudah selepas latihan dan kursus pendek dilakukan atau dengan bimbingan daripada pakar gamifikasi (Jong, 2019; An et al., 2020).

Selain itu, kecekapan dalam menggunakan teknologi (Adukaite \& Cantoni, 2016; An et al., 2020), sambungan internet yang tidak stabil (Adukaite \& Cantoni, 2016), kekurangan sokongan dan sumber daya (Sánchez-Mena \& Martí-Parreño, 2017; An et al., 2020), dan dikekang untuk mendapatkan akses yang wajar ke teknologi bilik darjah atau sumber sekolah (Adukaite \& Cantoni, 2016; Pektaş \& Kepceoğlu, 2019; Mee et al., 2020) juga merupakan cabaran yang dihadapi oleh guru. Selanjutnya, kesesuaian mata pelajaran juga merupakan halangan lain bagi guru kerana guru menganggap gamifikasi tidak sesuai untuk semua mata pelajaran (Adukaite \& Cantoni, 2016; Sánchez-Mena \& Martí-Parreño, 2017; Pektaş \& Kepceoğlu, 2019; An et al., 2020; Mee et al., 2020). Hal ini mungkin disebabkan guru 
tidak mengetahui potensi gamifikasi dalam pendidikan dengan sepenuhnya dan mempercayai bahawa gamifikasi hanya dapat diterapkan pada sebilangan subjek sahaja (Sánchez-Mena \& Martí-Parreño, 2017).

Kajian An et al. (2020) menunjukkan beberapa responden yang ditemu ramah kelihatan bimbang tentang bagaimana pelajar akan melihat gamified MOOC. Pengajar MOOC merasakan bahawa sukar untuk melibatkan pelajar yang lebih tua dan berfikiran kritis dalam kursus gamifikasi. Ini dipersetujui oleh kajian Mee et al. (2020) yang menyatakan bahawa kesukaran untuk menilai prestasi atau pembelajaran pelajar dengan permainan. Persepsi pembaziran masa untuk mengaplikasi gamifikasi turut diutarakan oleh guru dalam kajian Sánchez-Mena \& Martí-Parreño (2017) dan Pektaş \& Kepceoğlu (2019). Aplikasi gamifikasi memerlukan terlalu banyak masa. Hal ini mungkin akan menimbulkan kekurangan minat pelajar terhadap kursus gamified yang seterusnya menyebabkan guru merasakan usaha menyediakan kelas gamified tidak berbaloi kerana pelajar tidak menghargainya dengan betul. Beberapa aplikasi gamifikasi adalah terlalu rumit bagi pelajar. Contohnya, antara muka Socrative yang berbahasa Inggeris menyukarkan penggunaan pelajar yang tidak tahu bahasa Inggeris (Çetin \& Solmaz, 2020).

\section{Persepsi Guru Terhadap Bagaimana Gamifikasi Memotivasi Pelajar}

Persepsi guru terhadap penggunaan gamifikasi dalam pengajaran dan pembelajaran juga dapat dilihat melalui bagaimana ia memotivasi pelajar untuk belajar. Motivasi memainkan peranan besar dalam proses pembelajaran. Tanpa motivasi, pelajar tidak dapat mengetahui mengapa mereka harus mempelajari sesuatu topik. 8 daripada 15 artikel kajian telah membincangkan persepsi guru terhadap bagaimana gamifikasi memotivasikan pelajar. Dalam kajian yang dilakukan oleh Pektaş \& Kepceoğlu (2019) mendapati 39\% guru yang menjadi responden bersetuju bahawa aplikasi gamifikasi dalam pendidikan meningkatkan motivasi pelajar dalam kursus kerana aplikasi tersebut adalah baru dan menarik bagi pelajar pertama kali menggunakannya. Dengan bantuan aplikasi, soalan dapat difahami dengan lebih baik dan kekal. Kursus-kursus menjadi komprehensif dan menghiburkan. Ini selari dengan kajian Sánchez-Mena dan Martí-Parreño (2017), para guru yang ditemu ramah semasa proses pengumpulan data berpendapat bahawa penggunaan metodologi inovatif (gamifikasi) di dalam kelas dapat meningkatkan perhatian dan motivasi pelajar dengan berkesan. Oleh itu, guru sebagai agen perubahan mesti sentiasa mengetahui dan mengaplikasikan alat pengajaran dan pembelajaran terkini bagi memastikan para pelajar dapat belajar dengan berkesan.

Menurut Alabbasi (2018), penggabungan elemen permainan dalam pembelajaran membolehkan pelajar memperoleh lencana yang banyak setelah menyelesaikan sesuatu tugasan yang ditetapkan. Sifat ingin menang pelajar dan persaingan persahabatan memotivasikan mereka berusaha keras untuk mencapai tujuan tersebut. Secara langsung, pelajar akan mengingati isi pembelajaran tanpa disedari. Bentuk penghargaan dan ganjaran ini menjadi pendorong kepada pelajar untuk menunjukkan prestasi melebihi jangkaan guru dan keperluan kursus. Penglibatan pelajar dalam pembelajaran secara aktif juga digalakkan (Başal \& Kaynak, 2019). Tambahan lagi, pelajar juga termotivasi untuk belajar ketika mereka menggunakan gamifikasi kerana mereka belajar dalam persekitaran yang menyeronokkan, selesa, dan kondusif dengan mesra pertandingan (Adukaite \& Cantoni, 2016; Sánchez-Mena \& MartíParreño, 2017; Başal \& Kaynak, 2019; Pektaş \& Kepceoğlu, 2019; Fernandez-Rio et al., 2020). Oleh itu, boleh dikatakan secara umum, guru setuju bahawa gamifikasi adalah alat yang baik untuk digunakan dalam pengajaran dan pembelajaran kerana ia dapat memotivasi pelajar untuk belajar dan meningkatkan pencapaian akademik (Gómez-Carrasco et al., 2019; Fernandez-Rio et al., 2020; Yaşar et al., 2020).

\section{Persepsi Guru Terhadap Kesan Negatif Gamifikasi terhadap Murid}

Gamifikasi adalah strategi pendidikan yang semakin popular dan telah terbukti mendatangkan banyak keberkesanan dalam pengajaran dan pembelajaran. Namun begitu, ia juga dapat menimbulkan kesan negatif terhadap murid. Sebanyak 6 daripada 15 kajian membincangkan persepsi guru berkaitan kesan negatif gamifikasi terhadap murid. Gamifikasi didasarkan pada prinsip motivasi ekstrinsik di mana pelajar akan bekerja keras untuk mendapatkan ganjaran. Penggunaan elemen permainan menjadikan pelajar lebih fokus untuk memperoleh mata daripada memahami kursus secara berkesan (Alabbasi, 2018; An et al., 2020; Mee et al., 2020). Ganjaran hanya memberikan peningkatan jangka pendek. 
Motivasi intrinsik pelajar untuk belajar akan menurun pada akhirnya. Beberapa aplikasi gamifikasi seperti Kahoot yang mengehad masa menyebabkan pelajar memberikan jawapan yang salah atau tanpa pemikiran yang masak. Sekiranya pelajar memberikan jawapan yang salah secara berturut-turut boleh menyebabkannya kehilangan keyakinan diri dan seterusnya kehilangan motivasi untuk belajar (Pektaş \& Kepceoğlu, 2019).

Menurut An et al. (2020), gamifikasi mungkin akan mengalih perhatian pelajar dan bukannya meningkatkan pembelajaran mereka. Oleh itu, guru haruslah memastikan reka bentuk permainan yang baik dan menyokong kurikulum dan pembelajaran sebelum mengimplementasikannya dalam pengajaran. Kajian Yaşar et al. (2020) menyatakan kesan negatif yang paling biasa dikesan dalam aplikasi gamifikasi adalah kecemburuan yang ditunjukkan oleh pelajar terhadap rakan sebaya. Tingkah laku pelajar seperti kemunduran, dendam terhadap rakan sebaya, pengabaian, tingkah laku negatif terhadap rakan sebaya, keputusasaan, kesedihan, dan kerosakan fizikal pada elemen gamifikasi juga dikenal pasti. Ini selari dengan hasil kajian yang dilakukan oleh Alabbasi (2018) yang menunjukkan bahawa sebilangan kecil guru yang signifikan menganggap elemen permainan sebagai pendorong sifat negatif pada pelajar.

\section{Kesediaan Guru untuk Terus Menggunakan Gamifikasi}

Hasil dapatan terhadap kesediaan guru untuk menggunakan gamifikasi dalam pengajaran juga dapat dilihat dalam artikel terpilih. Sebilangan besar guru dalam kajian yang dijalankan mempunyai pandangan positif terhadap gamifikasi dan telah bersedia menggabungkan platform ini pada masa akan datang. Hasil kajian berkaitan kesediaan guru untuk menggunakan gamifikasi ditunjukkan dalam Jadual 3.

Jadual 3: Kesediaan guru untuk menggunakan gamifikasi

\section{Pengarang}

\section{Kesediaan Menggunakan Gamifikasi}

Bersedia Tidak Bersedia Tidak Dibincangkan

Yunjo An et al. (2020)

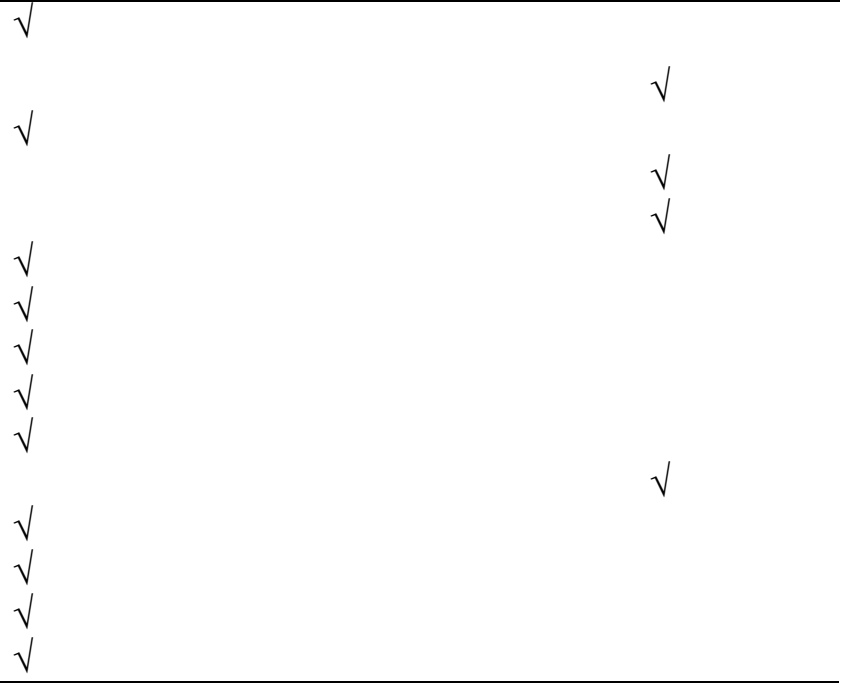

Asiri, M. (2019)

H. Yaşar et al. (2020)

Sánchez-Mena \& Martí-Parreño (201:

Fernandez-Rio, J et al. (2020)

Ekmel Çetin, Ebru Solmaz (2020)

Jong, M (2019)

Adukaite, A and Cantoni, L (2016)

Başal, A. \& Kaynak, N. E. (2019)

Martí-Parreñoa, J et al. (2016)

Mee et al. (2020)

Alabbasi, D. (2018)

Pektaş, M. \& Kepceoğlu, I (2019)

Tuparova, D. et al. (2018)

Gómez-Carrasco, C. et al. (2019)

Seperti yang dilihat pada Jadual 3, 11 dari 15 artikel kajian yang dikenal pasti menyatakan bahawa guru bersedia terus menggunakan gamifikasi dalam pengajaran dan pembelajaran masa depan. Guru melihat gamifikasi sebagai alat yang sangat efektif kerana mewujudkan persekitaran pembelajaran yang menyeronokkan untuk pelajar (Adukaite \& Cantoni, 2016; Sánchez-Mena \& Martí-Parreño, 2017; Başal \& Kaynak, 2019; Pektaş \& Kepceoğlu, 2019; Fernandez-Rio et al., 2020). Dengan itu, tidak hairanlah jika pelajar berasa bosan di dalam kelas apabila gurunya hanya menggunakan kaedah trandisional untuk mengajar, terutamanya pengajaran berpusatkan guru (Sánchez-Mena \& Martí-Parreño, 2017). Pelajar harus diberi autonomi untuk mengawal pembelajaran mereka sendiri. Sebagai seorang pelajar yang berdikari, sikap bertanggungjawab dapat dipupuk, selain memotivasi pelajar untuk menjadi lebih baik (Adukaite \& Cantoni, 2016). Ini dapat mendorong pelajar untuk mencapai hasil dan kemahiran yang 
lebih baik dalam pembelajaran. Dengan pemikiran ini, guru pasti akan terus menggunakan gamifikasi dalam pengajaran dan pembelajaran.

\section{Kesimpulan}

Tinjauan sistematik ini menganalisis persepsi guru mengenai penggunaan gamifikasi dalam pengajaran dan pembelajaran. Sebanyak 15 artikel dipilih dengan tiga pangkalan data iaitu IEEE Xplore, ERIC dan Science Direct. Persepsi guru dianalisis dari empat aspek yang berbeza, terutamanya, keberkesanan, kesukaran, motivasi dan kesan negatif. Secara keseluruhan, guru memberikan persepsi dan maklum balas positif terhadap pelaksanaan gamifikasi dalam pengajaran dan pembelajaran. Namun, masih ada ruang untuk gamifikasi diperbaiki untuk menghadapi kesan negatif yang dinyatakan.

Selain itu, tinjauan sistematik ini juga menganalisis kesediaan guru untuk terus menggunakan gamifikasi sebagai pedagogi pengajaran pada masa akan datang. Sebanyak 11 dari 15 artikel kajian yang dikenal pasti menyatakan bahawa guru bersedia terus menggunakan gamifikasi dalam pengajaran dan pembelajaran masa depan. Ini jelas menunjukkan bahawa gamifikasi telah memberi kesan yang besar kepada guru dan menyebabkan guru lebih menerima platform ini sekarang. Kepercayaan guru terhadap keberkesanan gamifikasi sebagai agen perubahan dapat memotivasikan dan mengubah pemikiran pelbagai lapisan masyarakat.

\section{Rujukan}

Adukaite, A., \& Cantoni, L. (2016). Raising awareness and promoting informal learning on World Heritage in Southern Africa: The case of WHACY, a gamified ICT-enhanced tool. International Journal of Education and Development using ICT, 12, 50-67.

Alabbasi, D. (2018). Exploring Teachers' Perspectives towards Using Gamification Techniques in Online Learning. Turkish Online Journal of Educational Technology, 17, 34-45.

Asiri, M. (2019). Do Teachers' Attitudes, Perception of Usefulness, and Perceived Social Influences Predict Their Behavioral Intentions to Use Gamification in EFL Classrooms? Evidence from the Middle East. International Journal of Education, 7, 112-122.

Basal, A., \& Kaynak, N.E. (2020). Perceptions of pre-service English teachers towards the use of digital badges. Innovations in Education and Teaching International, 57, 148 - 162.

Çetin, E., \& Solmaz, E. (2020). Gamifying the 9 Events of Instruction with Different Interactive Response Systems: The Views of Social Sciences Teacher Candidates. Malaysian Online Journal of Educational Technology, 8, 1-15.

Daniela, L. (2020). Concept of smart pedagogy for learning in a digital world. In Epistemological approaches to digital learning in educational contexts (pp. 1-16). Routledge.

Ding, L., Er, E., \& Orey, M. (2018). An exploratory study of student engagement in gamified online $\begin{array}{llllll}\text { discussions. } & \text { Computers } \& \quad \text { Education, } & 120, & 213 & -226 .\end{array}$ https://doi.org/10.1016/j.compedu.2018.02.007.

Domínguez, A., Saenz-de-Navarrete, J., de-Marcos, L., Fernández-Sanz, L., Pagés, C., \& MartínezHerráiz, J. J. (2013). Gamifying learning experiences: Practical implications and outcomes. Computers \& Education, 63, 380-392. https://doi.org/10.1016/j.compedu.2012.12.020

Fernández-Río, J., Heras, E.D., González, T., Trillo, V., \& Palomares, J. (2020). Gamification and physical education. Viability and preliminary views from students and teachers. Physical Education and Sport Pedagogy, 25, 509 - 524.

Ifenthaler, D., Eseryel, D., \& Ge, X. (2012). Assessment for game-based learning. In Assessment in game-based learning: Foundations, innovations, and perspectives (pp. 1-8). Springer.

Göksün, D. O., \& Gürsoy, G. (2019). Comparing success and engagement in gamified learning experiences via Kahoot and Quizizz. Computers \& Education, 135, 15-29. https://doi.org/10.1016/j.compedu.2019.02.015.

Gómez-Carrasco, C., Monteagudo-Fernández, J., Moreno-Vera, J., \& Sainz-Gómez, M. (2019). Effects of a Gamification and Flipped-Classroom Program for Teachers in Training on Motivation and Learning Perception. Education Sciences, 9, 299. 
Gough, D., Oliver, S., \& Thomas, J. (2012). Introducing systematic reviews. In D. Gough, S. Oliver, \& J. Thomas (Eds.). In introduction to systematic reviews (pp. 1-16). London, United Kingdom: Sage.

Groening, C., \& Binnewies, C. (2019). 'Achievement unlocked!' - the impact of digital achievements as a gamification element on motivation and performance. Computers in Human Behavior, 97, 151166. https://doi.org/10.1016/j.chb.2019.02.026.

Jong, M. (2019). Sustaining the adoption of gamified outdoor social enquiry learning in high schools through addressing teachers' emerging concerns: A 3-year study. Br. J. Educ. Technol., 50, 12751293.

Lopez, C. E., \& Tucker, C. S. (2019). The effects of player type on performance: A gamification case study. Computers in Human Behavior, 91, 333-345.

Martí-Parreño, J., Seguí-Mas, D., \& Seguí-Mas, E. (2016). Teachers' attitude towards and actual use of gamification. Procedia - Social and Behavioral Sciences, 228, 682-688.

Mee, R.W., Shahdan, T.S., Ismail, R., Ghani, K.A., Pek, L.S., Von, W.Y., Woo, A., \& Rao, Y.S. (2020). Role of gamification in classroom teaching: Pre-service teachers' view. International Journal of Evaluation and Research in Education, 9, 684-690.

Metaari. (2019). About us. Diakses dari http://metaari.com/about.html (10.6.2021).

Moher, D., Liberati, A., Tetzlaff, J., \& Altman, D. G. ThePrismaGroup. (2009). Preferred reporting items for systematic reviews and meta-analyses: The PRISMA statement. PLoS Medicine, 6(7), e1000097. http://dx.doi.org/10.1371/journal.pmed.1000097

Pektaş, M., \& Kepceoglu, I. (2019). What Do Prospective Teachers Think about Educational Gamification. Science education international, 30, 65-74.

Pew Research Centre. (2012). The Future of Gamification. https://www.pewresearch.org/internet/2012/05/18/the-future-of-gamification/

Salen, K., \& Zimmerman, E. (2004). Rules of play-Game design fundamentals. Massachusetts Institute of Technology. https://gamifique.files.wordpress.com/2011/11/1-rules-of-play-game-designfundamentals.pdf

Sánchez-Mena, A., \& Martí-Parreño, J. (2017). Drivers and Barriers to Adopting Gamification: Teachers' Perspectives. Electronic Journal of e-Learning, 15, 434-443.

Schöbel, S., Janson, A., Jahn, K., Kordyaka, B., Turetken, O., Djafarova, N., et al. (2020). A research agenda for the why, what, and how of gamification designs resultson an ECIS 2019 panel. Communications of the association for information systems.

Tuparova, D., Tuparov, G., Veleva, V., \& Nikolova, E. (2018). Educational computer games and gamification in informatics and information technology education - Teachers' points of view. 2018 41 st International Convention on Information and Communication Technology, Electronics and Microelectronics (MIPRO), 0766-0771.

Yaşar, H., Kiyici, M., \& Karatas, A. (2020). The Views and Adoption Levels of Primary School Teachers on Gamification, Problems and Possible Solutions. Participatory Educational Research (PER), Vol. 7(3), pp. 265-279.

York, J., \& Dehaan, J. (2018). A Constructivist approach to game-based language learning: Student perceptions in a beginner-level EFL context. International Journal of Game-Based Learning, 8, 1940.

Zimmerling, E., Höllig, C. E., Sandner, P. G., \& Welpe, I. M. (2019). Exploring the influence of common game elements on ideation output and motivation. Journal of Business Research, 94, 302312. https://doi.org/10.1016/j.jbusres.2018.02.030. 